\title{
伝統木造軸組の実大振動実験・静的水平力載荷実験 FULL-SCALE DYNAMIC AND STATIC TESTS OF TRADITIONAL WOODEN FRAME
}

\author{
鈴木祥 之*，前野将 輝**，西塔純 人***，北 原昭 男**** \\ 後藤正美*****, 須田達*****, 大下達哉******* \\ Yoshiyuki SUZUKI, Masaki MAENO, Sumito SAITO, Akio KITAHARA, \\ Masami GOTOU, Tatsuru SUDA and Tatsuya OHSHITA
}

\begin{abstract}
To clear the response characteristics of Japanese traditional wooden buildings, shaking table tests and static lateral loading tests using a full-scale model of traditional wooden frame were carried out. From experiments, it is found that traditional wooden frame has high performance of deformability and dumping. The hysteretic characteristics of the whole frame obtained from shaking table tests correlate closely with those of static tests. The whole restoring force increases in proportion to increase of vertical load acting on the column capitals in the model with the minimum figuration of tie-beam. The effect of the frames with ' without tie-beams on the restoring force were also examined. Then, the restoring force characteristics due to column rocking and the moment resistance of tie-beam play important roles in structural mechanism of traditional wood buildings.
\end{abstract}

Keywords: Japanese traditional wooden frame, Shaking table tests, Static lateral loading tests, Response characteristics,

Hysteretic characteristics, Damage condition

伝統木造軸組，振動台実験，静的水平力載荷実験，応答特性，復元力特性，破壊性状

\section{1. 序}

我が国の伝統的な木造建築物は、独特の構造的特徵を有する軸組 構法を主要な構法として育まれてきた。構造的特徴として、大径柱 による柱傾斜復元力特性、複雑な木組みによる組物の減衰性能、柱 一貫接合部のめり込み抵抗、柱脚のすべり挙動などが挙げられる。 しかし、木組みの複雑さや木材の不均質性・不確定性ゆえに、詳細 な構造解析が極めて難しく、その結果、永年にわたる大工棟梁の知 恵が積み重なって築かれてきた構法が構造力学的に解明されていな い。また、壁量規定に基づく現行の木造建物の耐震設計法は、耐力 壁に支配され、伝統軸組構造には対応していない。一方で文化財と しての社寺建築など伝統的木造建築物の保存. 修復技術の早期開発 が要望されている。このような現状から、棈造的特徴の把握を目的 とした実験的研究(1)-6)が行われてきた。

柱傾斜復元力特性については、坂"が社寺骨組の力学的研究を行 い、鉛直荷重作用時の変位と復元力の関倸を実験的に求め、実際の 復元力は柱が完全な剛体である場合と比較して小さくなることを㭘 証し、柱傾斜復元力の定式化を行っている。また、河合 ${ }^{2)}$ が柱上端 及び下端にめり込みが生じているとして円柱、角柱のモデル化を行 い柱の浮き上がり前後における柱傾斜復元力の算定式を提案する とともに、静的実験を行い、坂の研究を参考に定式化を行ってい る。

柱一貫接合部については、坂 ${ }^{31}$ が社寺骨組の力学的研究の中で貫
の耐力についての研究を行い、貫の耐力は柱が貫に比べて著しく太 い場合は貫の位置に無関係であること、貫が復元力を発生する場 合、柱の復元力に貫により生じる復元力を加算しなければならない などを知見として挙げている。また、後藤 ${ }^{4}$ が貫通仕口による木造 ラーメン構造の研究を行い、貫通構造の㓮性は小さく、実際には太 い柱を必要とすることなどを知見として挙げている。

組物については、藤田らが伝統的木造建築の組物の振動実験 ${ }^{5}$ 及 び静的水平力載荷実験 6 )を行っている。振動実験の結果から、組物 を構成する要素が増えるほど剛性、固有振動数は低下し、减衰定数 は大きくなること、組物試験体を 1 質点せん断系モデルとした地震 态答解析の結果が実験結果とよく一致することなどを知見として举 げている。また、静的実験から、マルチリニア型の履歴モデルを提 案し、剛性を木材のめり込み理論から算出して、実験結果と理論值 を比較することで、組物の剛性をその形状や材料特性から推定する 方法を提案している。

しかし、これらの既往の研究は、伝統木造軸組の部分的な構造要 素の構造的特徵を把握するために行われた模型実験や実大静的実験 であり、多くの構造要素からなる伝統木造軸組の実大試験体による 振動実験が行われておらず、実際の伝統木造構造物の地震時举動や 相互関連を有する各構造要素の力学的特性を把握することが困難で ある。また、伝統木造構造物の破壊性状はほとんど解明されておら ず、伝統木造構造物の地震被害を想定する上で变形性能と破壊性状
* 京都大学防災研究所 教授・I博

** 京都大学大学院工学研究科 博士後期課程·工修

*** 京都大学大学院工学研究科 修士課程

**** 鳥取環境大学環境デザイン学科 助教授・博士 (工学)

***** 金沢工業大学建築学科 助教授 $\cdot$ 博士 (工学)

****** 木四郎建築設計室 工修

******* 秼ジェイホーム 工修
Prof., Disaster Prevention Research Institute, Kyoto University, Dr. Eng. Graduate School of Engineering, Kyoto University, M. Eng. Graduate School of Engineering, Kyoto University

Assoc. Prof., Tottori University of Environmental Studies, Dr. Eng.

Assoc. Prof., Kanazawa Institute of Technology, Dr. Eng.

Kishirou Architectural Design Office, M. Eng.

J-Home Corp., M. Eng. 
を明らかにする必要がある。

そこで、写真 1 に示すような伝統的木造建築物が有する構造力学 的特徴を盛り込んだ実大軸組試験体を製作し、振動台実験及び静的 水平力載荷実験を行った。まず 2 章では、本実験の概要を述べ、実 験終了後に行った材料実験結果について示す。3章では、一連の振 動実験及び静的実験結果について述べる。

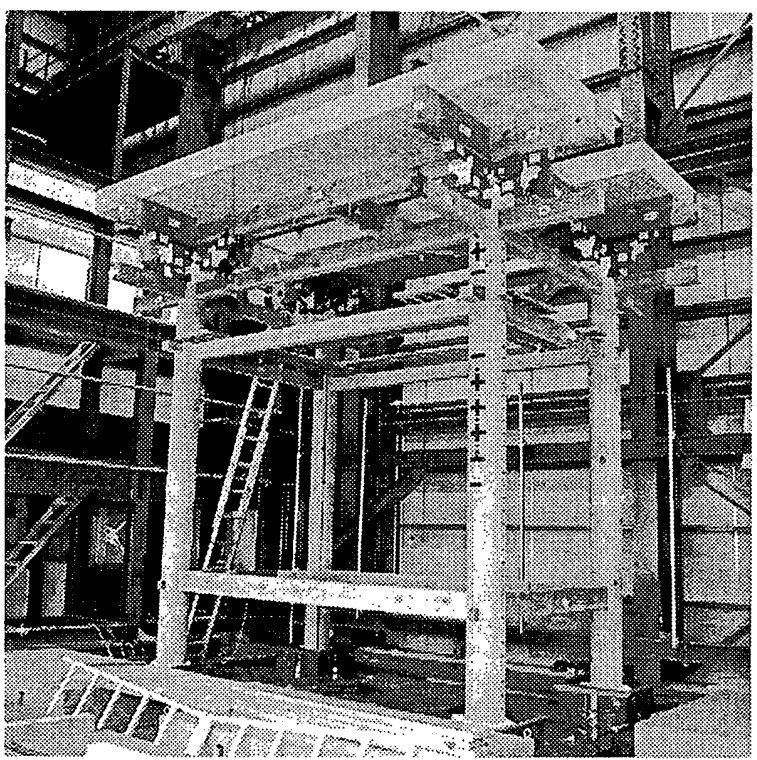

写真 1 試験体全体写真

\section{2. 実大振動台実験・静的水平力載荷実験の概要}

本実験 ${ }^{7-9)}$ は、京都大学防災研究所強震応答実験室において、 1999 年、2000 年、2001年の 3 期にわたって実施した。本研究では それぞれ第 1 期、第 2 期、第 3 期実験と称する。表 1 に各実験の実 験日程と実験主目的、表 2 に実験進行手順を示す。

\section{1 試験体概要}

第 1 期実験に使用した試験体を図 1 に、第 2 期及び第 3 期実験に 使用した試験体を図 2 に示す。試験体は 1 スパン× 1 スパン (3. $75 \mathrm{~m} \times 2.25 \mathrm{~m})$ の 4 本柱立体軸組であり、高さは礎石を含めて約 $5 \mathrm{~m}$ とした。これは実在する社寺建築のほほ実物大とし、伝統的な 軸組構法の典型的な特徴である、礎石の上に置いただけの大径柱、 柱一貫構造、組物を盛り込んだ実験モデルである。なお、試験体に 用いた木材は、柱が国産七ノキ、組物はアフリカ産アサメラ、その 他の部材は北米産ベイマツとした。楔は第 1 期及び第 2 期実験では アサメラ、第 3 期実験ではヒノキとした。

礎石は花岡岩（御影石）を使用し、その表面をびしゃん仕上げて 平滑にした。振動台上に固定された礎石の上に、柱を金物やダボな どで固定することなく設置した。

横架材は頭貫、内法貫、大引で構成した。各接合部は釘を一切使 わずに、仕口を用いて接合した。頭貫は柱頭部に相久きで接合し、 上から組物を載せて固定した。第 1 期試験体における内法貫は断面 欠損を伴わない通し貫で、長手方向貫及び短手方向貫が互いに交わ らないように、図1に示すように上下にずらして接合し、楔によっ て固定した。第 2 期以降の試験体における内法貫は相欠きで接合 し、長手短手両方向から楔を用いて固定した。また、第 1 期試験体 と第 2 期以降の試験体で、内法貫の仕口形状及び頭貫と内法貫の断 面寸法を変更した。頭貫及び内法貫の梁せいを約 $10 \%$ 小さくし、そ
れぞれ $202 \mathrm{~mm}$ から $181 \mathrm{~mm} 、 174 \mathrm{~mm}$ から $155 \mathrm{~mm}$ に変更した。これは、 仕口形状や断面寸法の変更が、試験体の動特性や復元力特性に与え る影響を把握するためである。大引は断面を切り欠いたほぞを、柱 のほぞ穴に差し込んだ単純な通しほぞによって接合した。第 2 期以 降の試験体における各貫の仕口のディテールを図 3 に示す。

柱頭部の組物は、时木を十字に組んで枠肘木とし、その上に斗を 置いた出三斗形式とし、接合に釷を一切使わないダボ接合により頭 貫の上に設置した。図 4 に組物詳細図を示す。そして、組物上に桁 梁を設置し、その上部に屋根荷重に相当するコンクリート製板状の 重り約 $54.8 \mathrm{kN}$ (5.59ton) を 2 枚設置した。その際、重り自体が新 たな振動系を構成しないようボルトで桁梁に固定した。その他、ね じれの影響を少なくし、平面的な剛性を上げるために桁梁、頭貫、 大引レベルの四隅に火打を取り付け、ボルトで固定した。

また、第 3 期実験では、火打効果や貫効果を把握するために、柱 と頭貫、内法貫、大引で構成された試験体 $\mathrm{A}$ を基本試験体とし、試 験体 $\mathrm{A}$ から大引火打を除いた試験体 B、試験体 $\mathrm{A}$ から内法貫を除い た試験体 $\mathrm{C} 、$ 、試験体 $\mathrm{A}$ から内法貫、長手方向大引、大引火打を取り 除いた試験体Dを用いて実験を行った。表 3 にそれぞれの試験体仕 様を示す。なお、試験体Dにおいて、ねじれの影響から試験体の倒 壊の恐れがあったために、短手方向の大引は残して実験を行った。 図 $5 \sim$ 図 7 に試験体 $B \sim D$ の試験体図を示す。

試験体の総重量（重りなし）は、第 1 期試験体で約 $30.5 \mathrm{kN}(3.11 \mathrm{t}$ on）、第 2 期試験体で約 $28.3 \mathrm{kN}$ (2.89ton)、第 3 期試験体 A で約 $28.6 \mathrm{kN}$ (2.92ton) であり、各試験体での重量差は、横架材の断面 寸法を変更したことや部材の乾燥収縮、損賃の大きかった部材を取 り替えたことによるものである。また、第 3 期実験試験体 $\mathrm{D}$ を使用 した静的水平力載荷実験では、鉛直荷重の増加による架構全体の復 元力に及ぼす影響を把握するために、析梁汢に設置した重りの増設 も行った。増設した重りは、約 $80.3 \mathrm{kN}$ (8.19ton) とした。

\section{2 振動台実験}

本振動実験では、まず試験体の動特性の把握を目的として、ス イープ波加振実験及び自由振動実験を行った。実地震動波加振実験 では、1940 E1 Centro及び1995 JMA Kobeの観測記録波形を主 とし、その他 1952 Taft、1968 Hachinohe を用い、振動状況や破 壊状況に応じて最大加速度振幅を徐々に上げつつ、繰り返して実験 を行った。加振方向は試験体長手 1 方向を主とし、水平 2 方向加振 も行った。また、静的水平力載荷実験との比較に用いた第 3 期試験 体Dによる振動実験では、試験体長手 1 方向のみ正弦波加振実験を 行った。用いた正弦波の卓越振動数は、試験体の持つ固有振動数近 傍とし、振動状況に応じて最大加速度振幅を徐々に上げつつ繰り返 して実験を行った。なお、本報では、El Centro NS、JMA Kobe NS 及び正弦波の長手 1 方向入力による実験結果を示す。

\section{3 静的水平力載荷実験}

本静的実験では、柱傾斜復元力を把握することを目的として、表 3 に示す柱一頭貫だけの単純な軸組構造である試験体Dを用いて実 験を行った。図 8 に静的実験概要を示す。本静的実験では、2枚の コンクリート製板にリブで補強した溝形鋼を渡し、その中央部にア クチュエータで加力した。また、加力に対して、試験体外周に設置 された鉄骨製の安全フレームを反カフレームとして用いることに よって反力を得た。 
表 1 実験の日程と主目的

\begin{tabular}{|c|c|c|}
\hline 実験期間 & 実験日程 & 実験主目的 \\
\hline 第 1 期 & $\begin{array}{c}1999 \text { 年10月 } 25 \text { 日 } \\
\sim 11 \text { 月 } 26 \text { 日 }\end{array}$ & $\begin{array}{l}\text { 損傷発生する変形レベルの把握 } \\
\text { 復元力特性の抽出 }\end{array}$ \\
\hline 第 2 期 & $\begin{array}{c}2000 \text { 年 } 9 \text { 月 } 22 \text { 日 } \\
\sim 11 \text { 月 } 16 \text { 日 } \\
\end{array}$ & \begin{tabular}{|l} 
試験体が転倒・破壊する危険のある \\
大変形レベルでの試験体の動抽出 \\
\end{tabular} \\
\hline 第 3 期 & $\begin{array}{c}2001 \text { 年5月 } 22 \text { 日 } \\
\sim 7 \text { 月 } 12 \text { 日 }\end{array}$ & 貫効果 - 柱傾斜復元力特性の把握 \\
\hline
\end{tabular}

表 2 実験の進行手順

\begin{tabular}{|c|c|c|c|}
\hline \multirow{9}{*}{$\begin{array}{c}\text { 第 } 1 \text { 期 } \\
\text { 実験 }\end{array}$} & 実験名 & 実験内容 & 実験目的・説明 \\
\hline & \multirow{2}{*}{ 実験 (I) } & スイープ・自由振動実験 & 地震動波入力前の動特性把握 \\
\hline & & 実地震動波加振実験 & 微少加振〜1/40rad程度まで \\
\hline & \multicolumn{3}{|c|}{ 仕口タイプ粘弹性ダンパーー付奏験 ${ }^{101}$} \\
\hline & \multirow{2}{*}{ 実験（II） } & スイープ・自由振動実験 & ダンパー付実験後の動特性把握 \\
\hline & & 実地震動波加振実験 & 変形角1/40rad程度までの加振 \\
\hline & \multirow{3}{*}{ 実験 (III) } & スイープ・自由振動実験 & 1/40rad変形経験後の動特性把握 \\
\hline & & 実地震動波加振実験 & 損傷が生じるまでの加振 \\
\hline & & スイープ・自由振動実験 & 地震動波入力後の動特性把握 \\
\hline
\end{tabular}

\begin{tabular}{|c|c|c|c|}
\hline \multirow{8}{*}{ 第 2 期 } & 実験名 & 実験内容 & 奏験目的. 説明 \\
\hline & \multirow{3}{*}{ 実験 (I) } & 常時微動計測 & 微少頒域の動特性把握 \\
\hline & & スイープ・自由振動実験 & 地震動波入力前の動特性把握 \\
\hline & & 実地震動波加振実験 & 微少加振〜1/40rad程度まで \\
\hline & \multicolumn{3}{|l|}{ 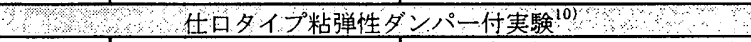 } \\
\hline & \multirow{2}{*}{ 実験 ( II) } & スイープ・自由振動実験 & 1/40rad変形経験後の動特性把握 \\
\hline & & 実地震動波加振実験 & 損傷が生じるまでの加振 \\
\hline & & 実地震動波加振実験 & 破壊に至るまでの大加振 \\
\hline
\end{tabular}

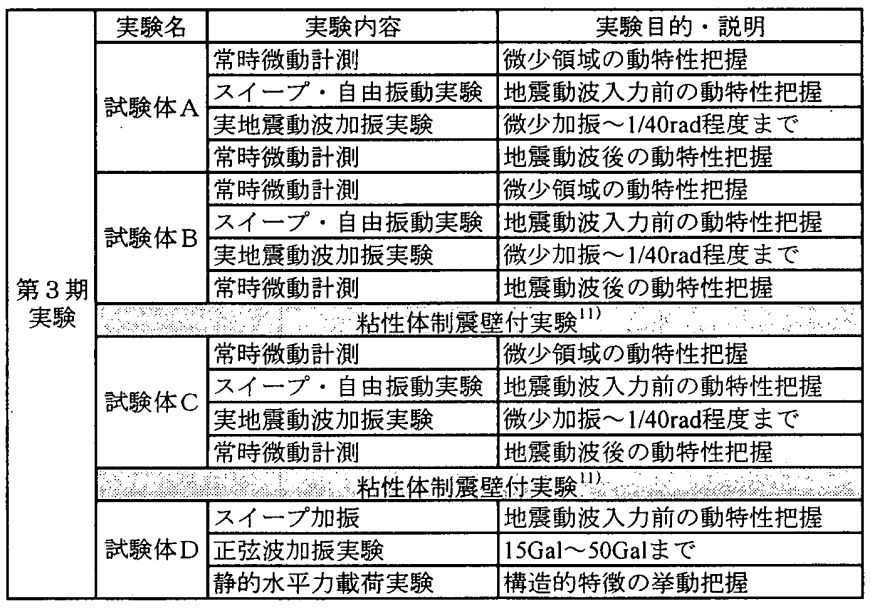

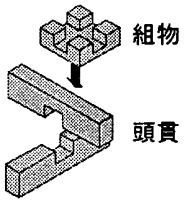

(a) 柱一頭貫接合部

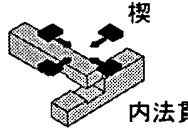

(b) 柱一内法貫接合部

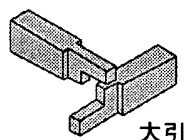

(c) 柱一大引接合部

\section{図 3 貫仕口詳細図}

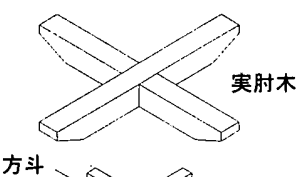

方斗

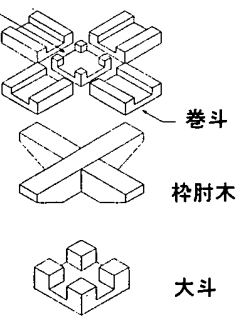

図 4 組物詳細図

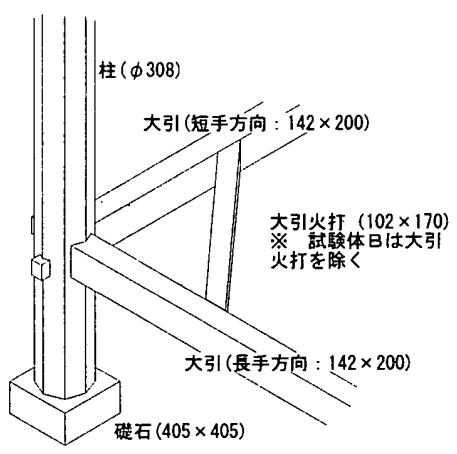

図 5 第 3 期試験体

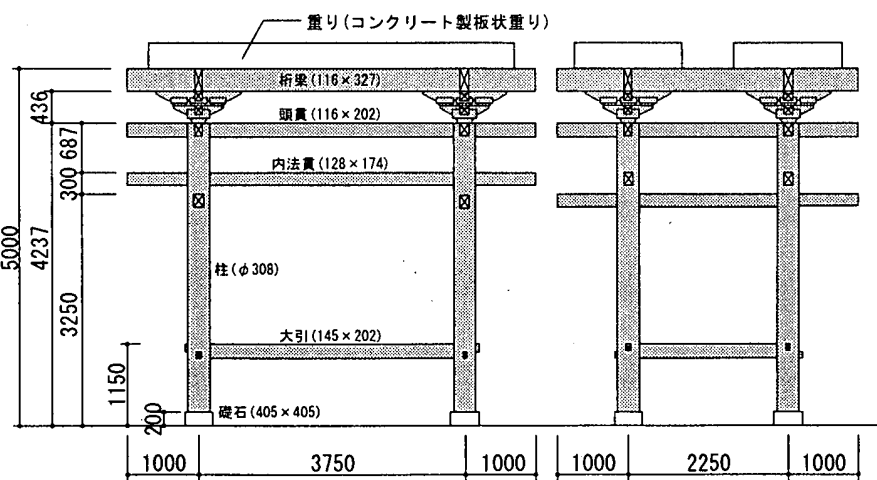

図 1 第 1 期試験体図

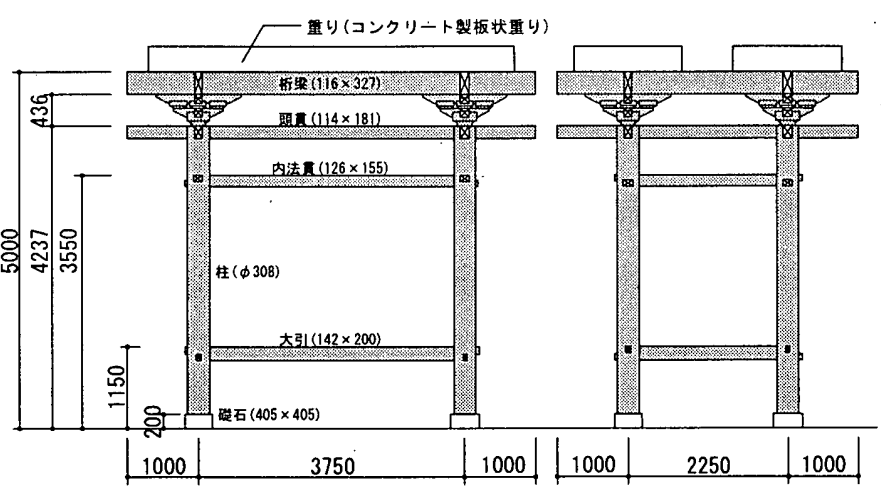

図 2 第 2 期 - 第 3 期試験体図

表 3 試験体の仕様

\begin{tabular}{|c|c|c|c|c|}
\hline \multirow[b]{2}{*}{ 試験体名 } & \multicolumn{3}{|c|}{ 試験体軸組部分の貫構成 } & \multirow{2}{*}{$\begin{array}{l}\text { 大引 } \\
\text { 火打 }\end{array}$} \\
\hline & 頭貫 & 内法貫 & 大引 & \\
\hline 試験体 A & $\mathrm{O}$ & 0 & $\mathrm{O}$ & $\mathrm{O}$ \\
\hline 試験体 B & 0 & 0 & 0 & \\
\hline 試験体 C & 0 & & 0 & 0 \\
\hline 試験体D & 0 & & & \\
\hline
\end{tabular}

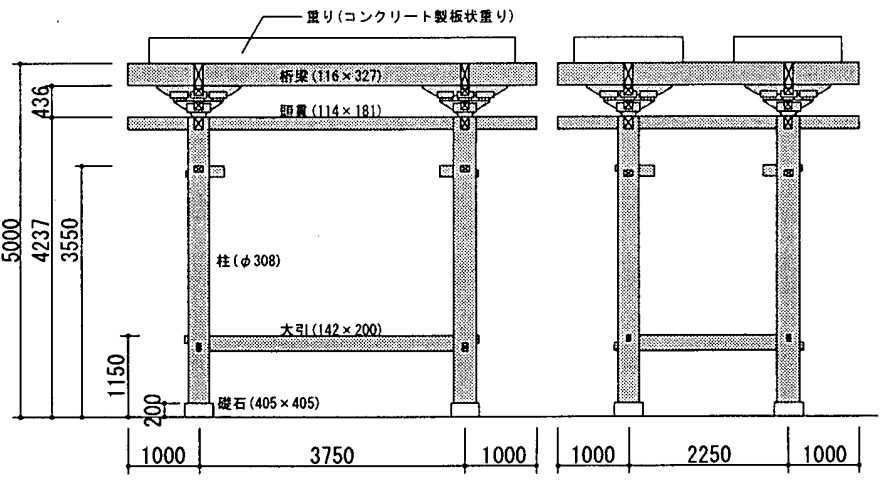

図6 第 3 期試験体C（内法貫なし）

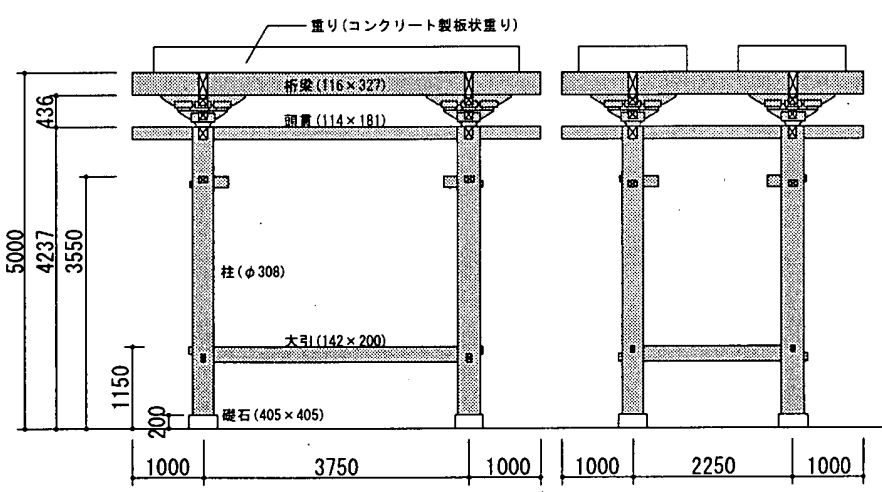

図 7 第 3 期試験体D（内法貫・大引なし） 


\section{4 計測計画}

図 9 に計測位置概要図を示す。試験体各部の変位計測について は、レーザー変位計及びワイヤー変位計を用いて計測した。主な計 測は、柱頭部及び柱脚部の水平変位、柱脚のすべり変位、頭貫と桁 梁の相対水平変位である。試験体各部の加速度計測については、半 導体型小型加速度計を用いて、振動台上、各柱の柱脚部、柱頭部、 桁梁、コンクリート製板上で計測た。柱と貫の相対回転角は、冶具 を用いて柱一貫接合部に斜めに取り付けた摺動式変位計から得られ た変位を用いて、幾何学的関倸より近似的に算出した。第 2 期実験 より、各部の挙動をより正確に把握するために、変位計、加速度計 に加え、柱軸力計測のためにロードセルを礎石の下に設置し、また 曲げモーメント計測のためにひずみゲージを試験体各部に取り付け た。第 2 期及び第 3 期実験で行った常時微動計測実験では、速度計 を振動台上、試験体の頭貫上、コンクリート製板上に設置して、計 測を行った。

\section{5 柱・買の材料特性}

第 1 期及び第 3 期実験の終了後に、試験体を解体し、京都大学木 質科学研究所において含水率及び動的ヤング係数の計測を行った 7)。含水率は高周波容量含水率計（(株) ケット科学研究所製：HM520）を、動的ヤング係数はハンドヘルドFFTアナライザー（(株） 小野測器製：CF-1200）を使用して計測した。第 3 期実験終了後に

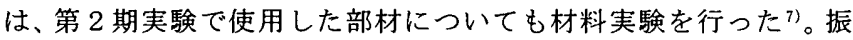
動実験においてひび割れが生じた試験体長手方向の内法貫、大引に ついては、3 等分点 4 点曲げ試験を行い、ヤング係数を計測した。 また、長手方向の頭貫についても同様に実験を行った。表 4 に結果 を示す。なお、表 4 中の値は各部材の平均値をそれぞれ示す。含水 率や部材寸法の計測では、部材の乾燥収縮の影響が見られた。ま た、非破壊的に求めた動的ヤング係数は、強度性能の推定に十分有 効であると考えられる。

\section{3. 実験結果}

\section{1 試験体の動特性}

表 5 に第 2 期及び第 3 期実験において計測した常時微動計測よ り、得られた速度フーリエスペクトルから求めた伝達関数を用いて 算出した試験体の固有振動数を示す。また、表 6 にスイープ波加振 実験より得られた加速度フーリェスペクトルから求めた伝達関数を 用いて算出した試験体の固有振動数を示す。また、表 7 に自由振動 実験より得られた変位データを用いて、隣り合う 1 周期ごとの振幅 比から算出した対数減衰率を示す。

表 5 より、常時微動計測から得られた第 3 期実験における試験体 の固有振動数は、第 2 期実験と比べて小さい值を示した。これは、 部材の乾燥収縮などによる木組みの緩みが原因と考えられる。ま た、試験体 $\mathrm{A} \sim \mathrm{D}$ の結果より、常時微動計測では、火打や貫を減じ た効果はほとんど見られなかった。

表 6 より、スイープ波加振から得られた試験体の固有振動数は、 第 1 期、第 2 期実験では実験段階が進むにつれて低下する傾向を示 した。また、試験体 $\mathrm{A} \sim \mathrm{D}$ の結果から、火打や貫を減じたことに よって、固有振動数が低下する傾向が明らかとなり、微少変形頜域 では現れなかった火打や貫の効果が示された。

表 7 より、自由振動実験から算出した試験体の対数减衰率は、長 手方向で約 $7 \sim 11 \%$ 、短手方向で約 $8 \sim 12 \%$ という高い值が計測 された。これは、本試験体のような伝統構法が持つ特有な柱一貫接 合部や、柱頭部に取り付けた組物など、多くの减衰要素による影響 により、高い减衰性能が得られたものと考えられる。

\section{2 試験体の破壊性状}

第 1 期及び第 2 期実験において、柱一貫接合部付近で損傷が確認 されている7)。本節では、損傷が生じた柱一内法貫及び柱一大引各 接合部について、実地震動波入力実験の進行状況と共に述べる。 （1）柱一内法貫接合部

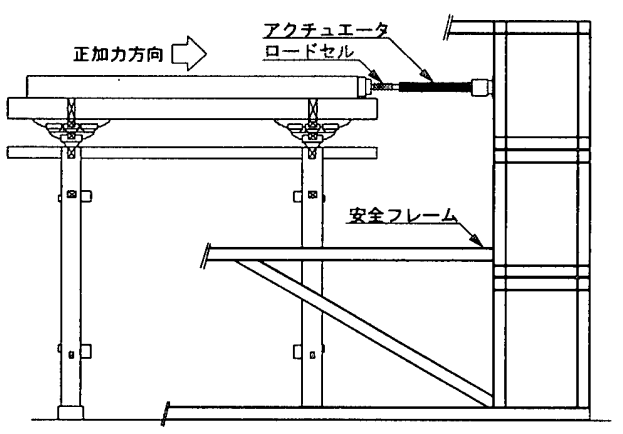

図 8 静的水平力載荷実験の概要図

表 5 常時微動計測による試験体の 1 次固有振動数 $(\mathrm{Hz})$

\begin{tabular}{|c|c|c|c|c|}
\hline \multicolumn{2}{|c|}{ 奏験名 } & \multirow{2}{*}{ 奏験段階 } & \multicolumn{2}{|c|}{ 方向 } \\
\hline & 試験体 & & 長手方向 & 短手方向 \\
\hline \multirow{2}{*}{\multicolumn{2}{|c|}{ 第 2 期 }} & 実験前 & 1.32 & 1.46 \\
\hline & & 実験後 & - & - \\
\hline \multirow{6}{*}{ 第 3 期 } & \multirow{2}{*}{ A } & 実験前 & 1.26 & 1.29 \\
\hline & & 実験後 & 1.15 & 1.29 \\
\hline & \multirow{2}{*}{ B } & 実験前 & 1.12 & 1.29 \\
\hline & & 実験後 & 1.11 & 1.28 \\
\hline & \multirow{2}{*}{ C } & 実験前 & 1.10 & 1.17 \\
\hline & & 害験後 & 1.11 & 1.17 \\
\hline
\end{tabular}

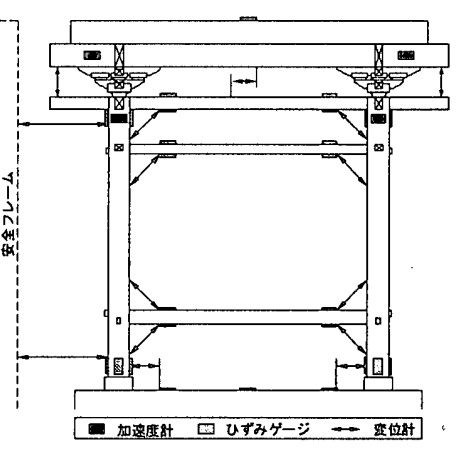

図 9 計測位置の概要図

表 4 部材の材料特性

\begin{tabular}{|c|c|c|c|c|c|c|}
\hline \multirow[t]{2}{*}{ 部材名 } & \multirow[t]{2}{*}{ 樹種 } & \multirow[t]{2}{*}{$\begin{array}{l}\text { 実験 } \\
\text { 奏施 } \\
\text { 期間 }\end{array}$} & 公称 & 含水率 & $\begin{array}{c}\text { 動的 } \\
\text { ヤング } \\
\text { 係数 }\end{array}$ & $\begin{array}{c}\text { 曲げ } \\
\text { ヤング } \\
\text { 係数 }\end{array}$ \\
\hline & & & $\mathrm{mm}$ & $\%$ & $\mathrm{~N} / \mathrm{mm}^{2}$ & $\mathrm{~N} / \mathrm{mm}^{2}$ \\
\hline \multirow{2}{*}{ 柱 } & \multirow{2}{*}{ 檜 } & 第1期 & $\varphi=308$ & 19.6 & 42 & \\
\hline & & 第3期 & $\varphi=3$ & & & 6.85 \\
\hline \multirow{2}{*}{ 行梁 } & \multirow{2}{*}{ 米松 } & 第1期 & $116 \times 3$ & & & \\
\hline & & 第3期 & $113 \times 3$ & 10 & 10.32 & 7.75 \\
\hline \multirow{2}{*}{ 頭貫 } & \multirow{2}{*}{ 米松 } & 第1期 & $116 \times 20$ & 19 & & \\
\hline & & 第3期 & $114 \times 1$ & 9 & & 9.12 \\
\hline \multirow{2}{*}{ 内法貫 } & & 第1期 & $128 \times 1$ & 18 & & 9.13 \\
\hline & & 第3期 & $126 \times$ & 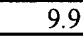 & & 10.52 \\
\hline \multirow{2}{*}{ र5 } & \multirow{2}{*}{ 米松 } & 第1期 & $145 \times 2$ & 18.0 & & 7.05 \\
\hline & & 第3期 & $142 \times 200$ & 11.2 & 12.71 & 10.71 \\
\hline
\end{tabular}

表 6 スイープ波加振実験による 試験体の 1 次固有振動数 $(\mathrm{Hz})$

\begin{tabular}{|c|c|c|c|c|}
\hline \multirow{2}{*}{\multicolumn{2}{|c|}{$\begin{array}{c}\text { 実験名 } \\
\text { 試験体 }\end{array}$}} & \multirow{2}{*}{ 実験段階 } & \multicolumn{2}{|c|}{ 方向 } \\
\hline & & & 長手方向 & 短手方向 \\
\hline \multirow{3}{*}{\multicolumn{2}{|c|}{ 第 1 期 }} & (I) 前 & 0.99 & 1.00 \\
\hline & & (II) 前 & 0.86 & 0.95 \\
\hline & & 終了後 & 0.77 & 0.92 \\
\hline \multirow{2}{*}{\multicolumn{2}{|c|}{ 第 2 期 }} & (I) 前 & 0.84 & 0.89 \\
\hline & & (II) 前 & 0.81 & 0.83 \\
\hline \multirow{4}{*}{ 第 3 期 } & $\mathrm{A}$ & 実験前 & 0.87 & 0.84 \\
\hline & $\bar{B}$ & 奏験前 & 0.77 & 0.79 \\
\hline & $\bar{C}$ & 実験前 & 0.66 & 0.76 \\
\hline & $\bar{D}$ & 実験前 & 0.50 & \\
\hline
\end{tabular}

表 7 自由振動実験による 試験体の対数减衰率 (\%)

\begin{tabular}{|c|c|c|c|c|}
\hline \multicolumn{2}{|c|}{ 実験名 } & \multirow{2}{*}{ 実験段階 } & \multicolumn{2}{|c|}{ 方向 } \\
\hline & 試験体 & & 長手方向 & 短手方向 \\
\hline \multirow{3}{*}{\multicolumn{2}{|c|}{ 第 1 期 }} & (I) 前 & 8.6 & 9.1 \\
\hline & & (II) 前 & 8.7 & 10.5 \\
\hline & & 終了後 & 10.0 & 10.6 \\
\hline \multirow{2}{*}{\multicolumn{2}{|c|}{ 第 2 期 }} & (I) 前 & 10.7 & 8.1 \\
\hline & & (II) 前 & 7.8 & 9.9 \\
\hline \multirow{4}{*}{ 第 3 期 } & $\bar{A}$ & 実験前 & 7.3 & 11.9 \\
\hline & B & 実験前 & 7.8 & 11.3 \\
\hline & $\bar{C}$ & 実験前 & 8.2 & 12.1 \\
\hline & $D$ & 実験前 & 7.4 & \\
\hline
\end{tabular}




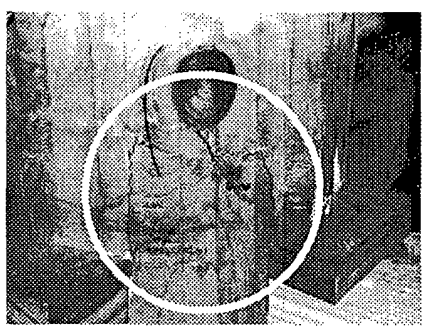

写真 2 柱一内法貫接合部の損傷 (柱部の割れ（第 2 期)）

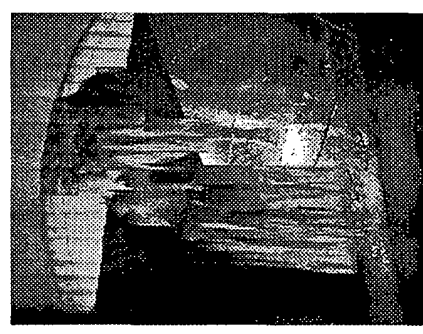

写真 3 大引仕口折損状況 (第 1 期実験)
ひび割れは変形角 $1 / 40 \mathrm{rad}$ 超える変形レベルより、柱一貫接合 部付近で発生することが目視により確認された。しかし、その後の 加振でひび割れは伸張したが、第 1 期、第 2 期実験共に貫自体の破 壊や折損には至らなかった。1/10 rad程度の大変形レベルでは内法 貫ではなく、柱側に損傷が見られるようになった。写真 2 は、第 2 期実験で、最大加速度振幅を700Galに調整したJMA Kobe NS波（以 後、JMA Kobe NS 700Gal のように記す。）入力時（最大層間変形 角 $1 / 14 \mathrm{rad}$ ）において、接合部付近の柱表面に生じたひび割れの様 子を示す。

\section{（2）柱一大引接合部}

写真 3 は、第 1 期実験終了後、解体時に確認された大引仕口の折 損の様子を示す。同様の折損は、第 2 期実験にも見られた。写真 3 より、ほぞ断面の最も小さい部分で折損していたことが分かる。ひ び割れは内法貫と同様、層間変形角1/40 radを超える変形レベルよ り多数発生することが確認されたが、折損は柱ほぞ穴内部で生じて いたため、目視だけの観察では折損に至る入力加振波を正確に把握 することは出来なかった。

\section{3 試験体の応答特性}

図 10 に、第 1 期実験のE1 Centro NS $400 \mathrm{Gal}$ 入力時（最大層 間変形角 $1 / 24 \mathrm{rad}$ ）における、振動台上、柱頭部、桁部の試験体長 手方向の水平加速度及び水平層間変位の時刻歴を示す。ここで、各 部の加速度は対象とする構面に該当する各柱における平均、柱一貫 軸組部の層間変位は柱頭部と柱脚部の水平变位の差から求めた。

柱頭部及び桁部の応答加速度を見ると、両者ともほほ同様の波形 を示している。また、柱一貫軸組部と組物部分の層間変位は変形レ ベルは大きく異なるがほぼ相似な波形を示し、概ね 1 次モードで振 動していることが明らかとなった。

\section{4 試験体の復元力特性}

\section{（1） 試験体の復元力特性}

図 11 に、第 1 期から第 3 期実験のE1 Centro NS $250 \mathrm{Gal}$ 入力 時における試験体長手方向の復元力特性を、図 12 及び図 13 に一連 のE1 Centro NS波、JMA Kobe NS波入力における試験体長手方向 の復元力特性の包絡曲線をそれぞれ示す。層せん断力は試験体の応 答加速度に試験体上部の重量を乗じ、層間変形角は柱頭部と柱脚部 の水平変位の差を柱高さで除して近似的に算出した。図 $12 、 13$ よ り、第 2 期及び第 3 期実験の復元力特性の包絡曲線は同様の傾向を 示し、第 1 期実験に比べて剛性が低下する傾向が見られたことか ら、内法貫仕口の形状を変更し、頭貫及び内法貫の梁せいを小さく した試験体を使用した影響が見られた。第 2 期実験より、柱一貫接 合部のひび割れが伸張し、層間変形角が $1 / 15 \mathrm{rad}$ 超えても耐力が 急激に低下する傾向はほとんどなく、大引折損の影響も見られない
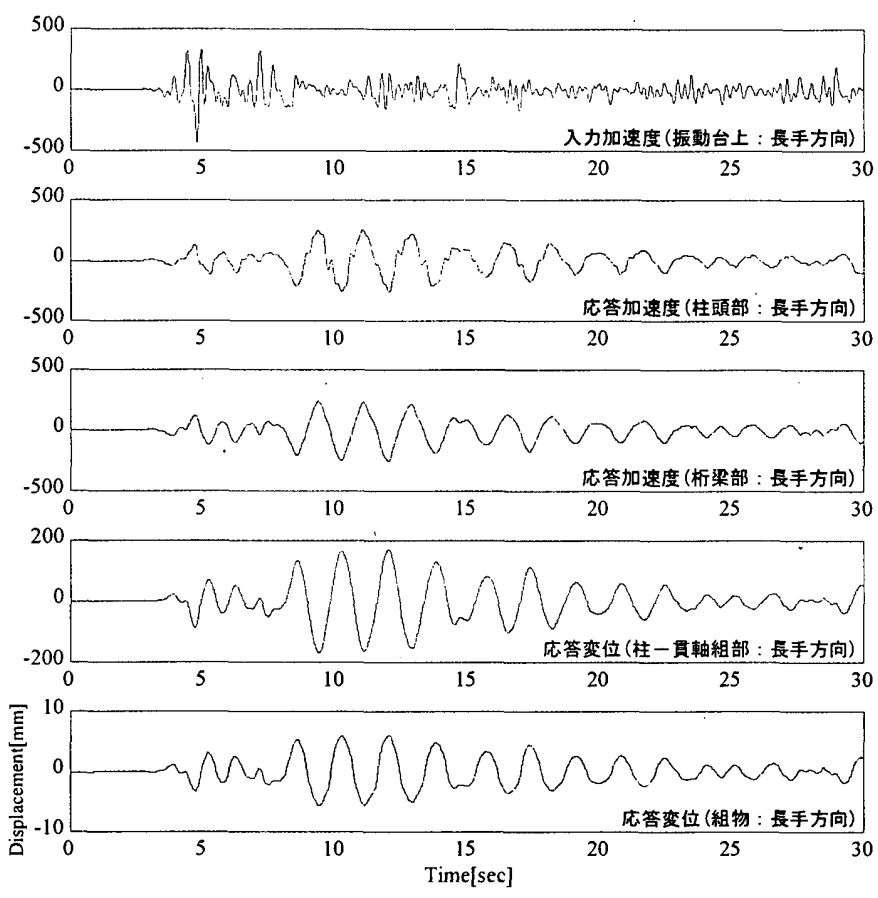

図 10 試験体の応答加速度 - 変位 (第 1 期 : El Centro NS 400Gal)

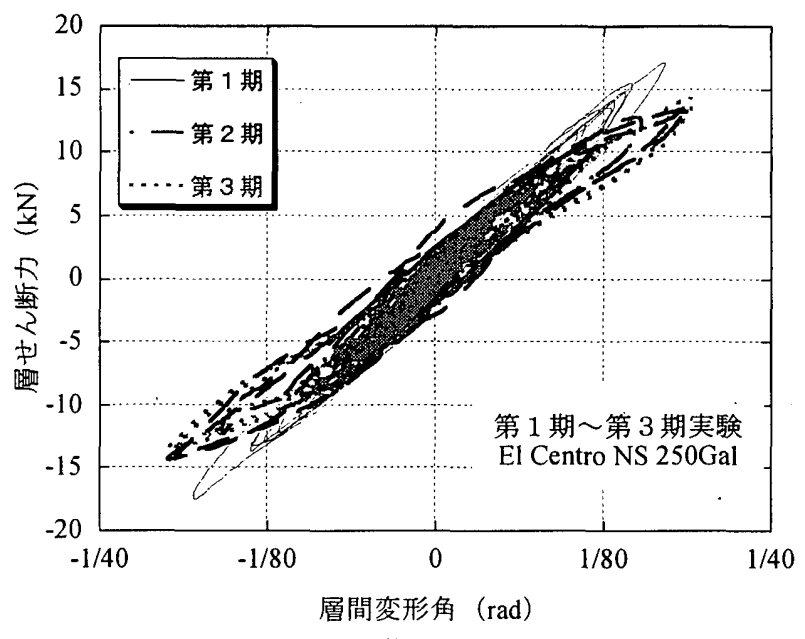

図 11 試験体の復元力特性

(El Centro NS 250Gal 入力時 : 長手方向)

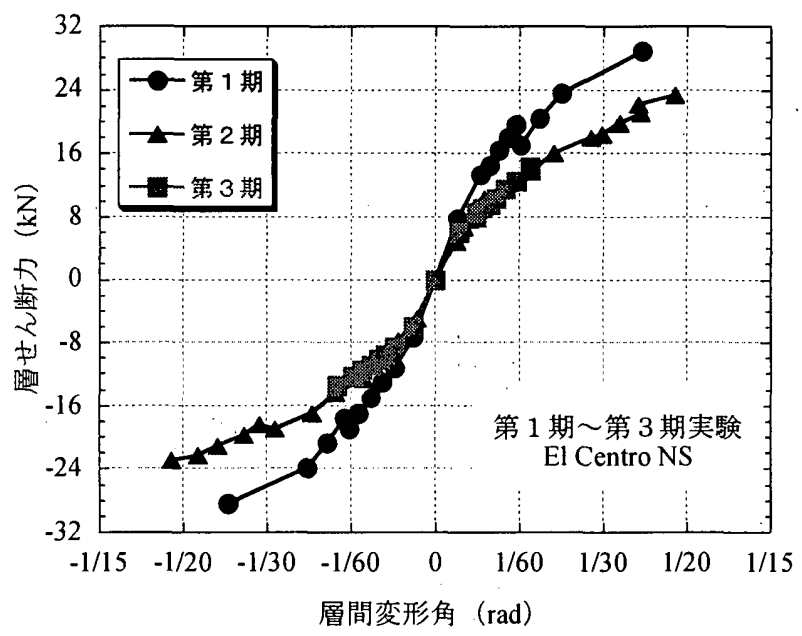

図 12 試験体の復元力特性の包絡曲線

(E1 Centro NS : 長手方向) 
ことから、伝統木造軸組は変形性能が高い構造と考えられる。

次に、火打や貫効果と復元力特性の変化について、図 14 に第 3 期試験体 A C C E 1 Centro NS 200Gal入力時における試験体長 手方向の復元力特性を、図 15 に一連のEl Centro NS 波入力実験 における試験体長手方向の復元力特性の包絡曲線を示す。図 $14 、 15$ より、貫を減じるに従って剛性、耐力が低下する傾向が見られた。

\section{（2）固有振動数の評価}

ここでは、第 3 期実験における実地震動波入力時の試験体の復元 力特性を利用して、試験体の固有振動数を算出し、火打や貫効果の 影響を示す。図16に、入力した全ての実地震波に対する試験体の 固有振動数を、試験体の復元力特性の割線剛性による等価固有振動 数から算出し、横軸にその最大層間変形角をとって図 16 に示す。

図16より、各試験体の等価固有振動数は、変形に寄らず試験体 $\mathrm{A}>$ 試験体 $\mathrm{B}>$ 試験体 $\mathrm{C}$ の関係を示した。変形角1/100 $\mathrm{rad}$ 程度で、 各試験体の等価固有振動数は試験体 $\mathrm{A}$ が約 $0.60 \mathrm{~Hz}$ 、試験体 $\mathrm{B}$ が約 $0.55 \mathrm{~Hz}$ 、試験体 Cが約 $0.40 \mathrm{~Hz}$ を示した。また変形角 $1 / 50 \mathrm{rad}$ 程度 で、試験体 $\mathrm{A}$ が約 $0.50 \mathrm{~Hz}$ 、試験体 $\mathrm{B}$ が約 $0.45 \mathrm{~Hz}$ 、試験体 $\mathrm{C}$ が約 $0.40 \mathrm{~Hz}$ を示した。試験体の固有振動数は、変形が進むと対数関数 的に減少する傾向が明らかとなり、内法貫を減じた試験体Cでその 傾向が強く見られた。

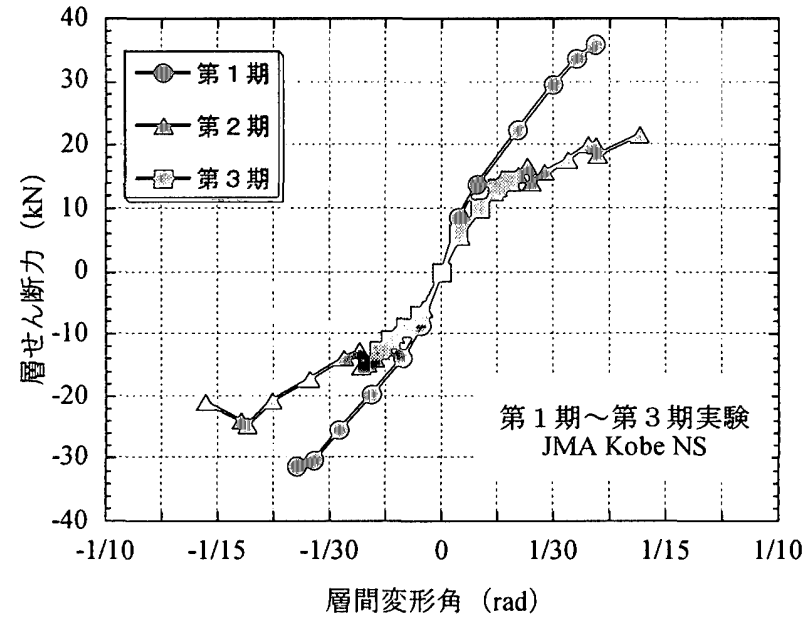

図13 試験体の復元力特性の包絡曲線 (JMA Kobe NS : 長手方向)

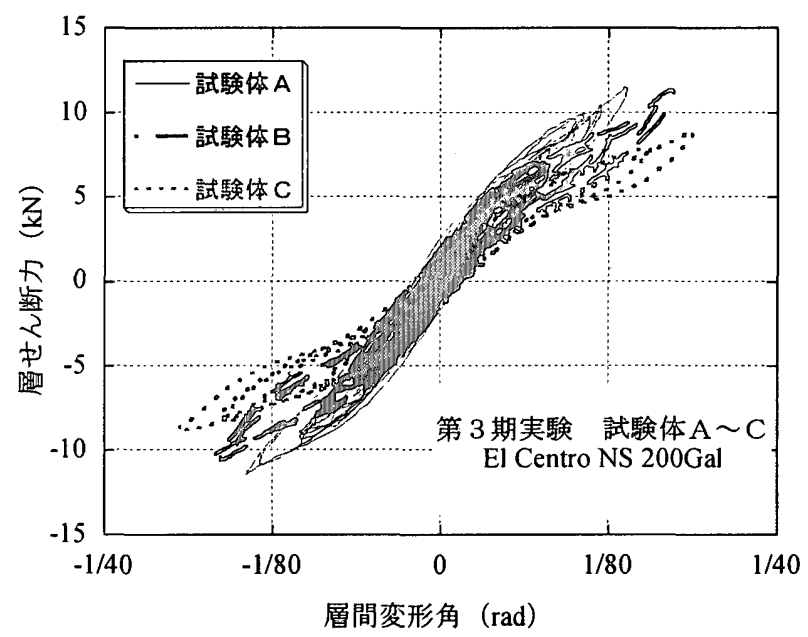

図 14 試験体の復元力特性（第 3 期試験体 $A \sim C$ ） (E1 Centro NS 200Gal 入力時: 長手方向)

\section{（3）等価減衰定数の評価}

ここでは、復元力特性の最大ループに着目し、最大ループ面積を そのループの最大変形時のポテンシャルエネルギーで除して等価減 衰定数 $\mathrm{h}_{\mathrm{eq}}$ 算出し、試験体の減衰性能評価を行った。図 17 に第 1 期 から第 3 期実験の一連のEl Centro NS 波及び JMA Kobe NS 波入 力における試験体の等価減衰定数を、図 18 に試験体 $\mathrm{A} \sim \mathrm{C}$ の一連 のEl Centro NS波入力における試験体の等価減衰定数を、横軸に その最大層間変形角をとってそれぞれ示す。

図 17 及び図 18 より、いずれの場合も約 $5 \sim 15 \%$ であり、比較的 高い減衰性能を示した。また、図 13 より火打や貫要素の変化と等 価減衰定数の变化に相関はほとんどなく、等価減衰定数には火打効 果や貫効果は見られなかった。

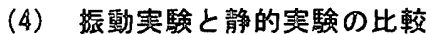

ここでは、試験体の復元力特性について、試験体Dの振動実験及 び静的実験結果の比較を行う。図 19 に、振動実験：正弦波 $0.60 \mathrm{~Hz}$ $35 \mathrm{Gal}$ 入力時及び静的実験: 変位量 $\pm 140 \mathrm{~mm}$ 加力時における試験体 の復元力特性を示す。図19より、振動実験結果と静的実験結果は 概ね一致しているといえる。

（5）鉛直荷画の增加による得元力特性の㖙化

ここでは、本静的実験で行った重りの増設による鉛直荷重の増加

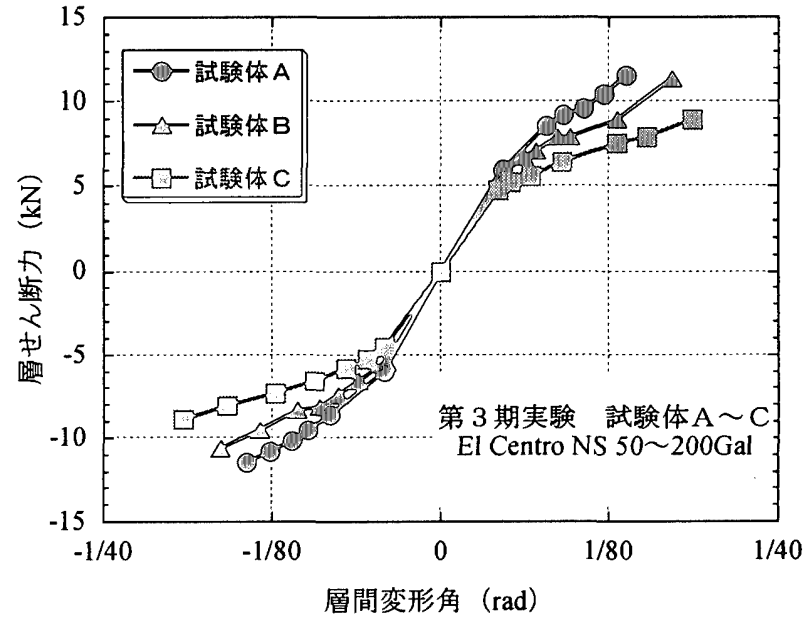

図 15 試験体の復元力特性の包絡曲線 （第 3 期試験体 A C El Centro NS：與手方向）

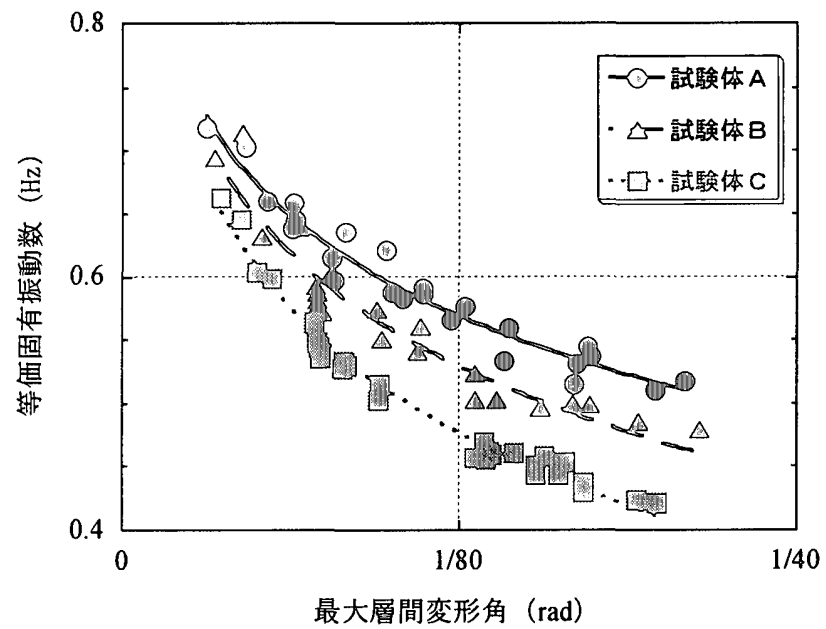

図16 全地震動入力時における試験体の等価固有振動数の変化 (第 3 期試験体 $\mathrm{A} \sim \mathrm{C}:$ 長手方向 $)$ 
が試験体の復元力特性に及ぼす影響について考察する。図20に、試 験体Dにおける重り増設あり静的実験: 変位量 $\pm 155 \mathrm{~mm}$ 加力時と、 重り增設なし静的実験:变位量 $\pm 190 \mathrm{~mm}$ 加力時の試験体の復元力特 性の比較を示す。既往の研究より 11,21 、柱傾斜復元力特性は履歷 ループを描くことなく、柱径の0.1倍程度を超える変形レベルから 負勾配となるが、試験体の復元力特性は、頭貫や組物などの効果が 加わり、履歴ループを描いており、急激に耐力低下することなく安 定した形状を保っている。試験体の最大復元力は、重り増設なし静 的実験において、正加力時で $4.89 \mathrm{kN}$ 、負加力時で $5.17 \mathrm{kN}$ を示した のに対し、重り增設あり静的実験では、正加力時で $7.37 \mathrm{kN}$ 、負加 力時で $7.65 \mathrm{kN}$ と增加している。柱 1 本当たりの鈆直荷重は、柱脚 部ロードセル計測値で約 $32.7 \mathrm{kN}$ (3.34ton) から約 $52: 8 \mathrm{kN}$ （5.39ton）に增加しており、161.5\%の鉛直荷重の増加に対して、 復元力は正加力側が $150.7 \%$ 、負加力側が $148.0 \%$ 增加を示した。 鉛直荷重の増加と試験体全体の復元力の増加は完全な比例関係では なく、復元力は鈆直荷重増加に対して正側、負側で $93.3 \% 、 91.6$ \%の増加にとどまっている。これは、頭貫や組物など鉛直荷重に関 わらない抵抗要素が含まれているためと考えられる。また、静的実 験で用いた試験体Dは、横架材が頭貫だけであったため、柱傾斜復 元力特性を顕著に見ることができた。

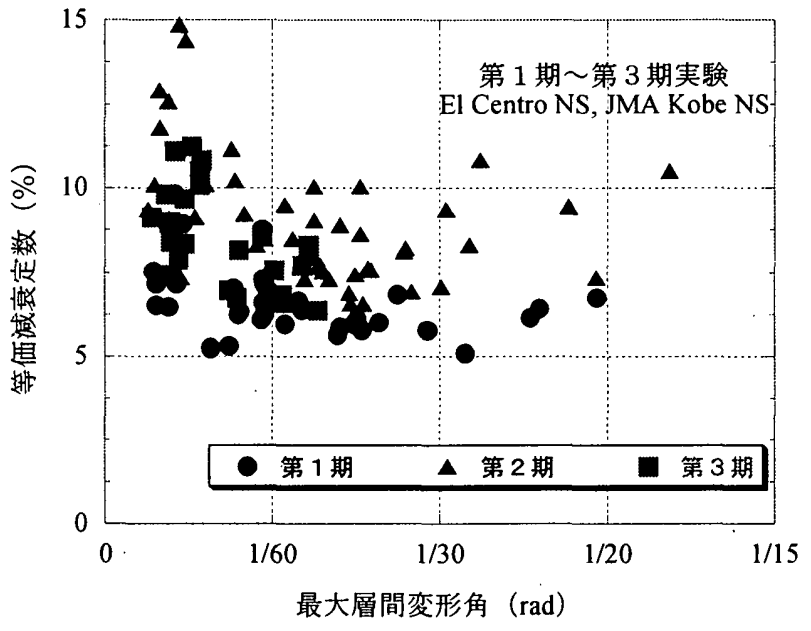

図 17 試験体の等価減衰定数の変化

(E1 Centro NS、JMA Kobe NS : 長手方向)

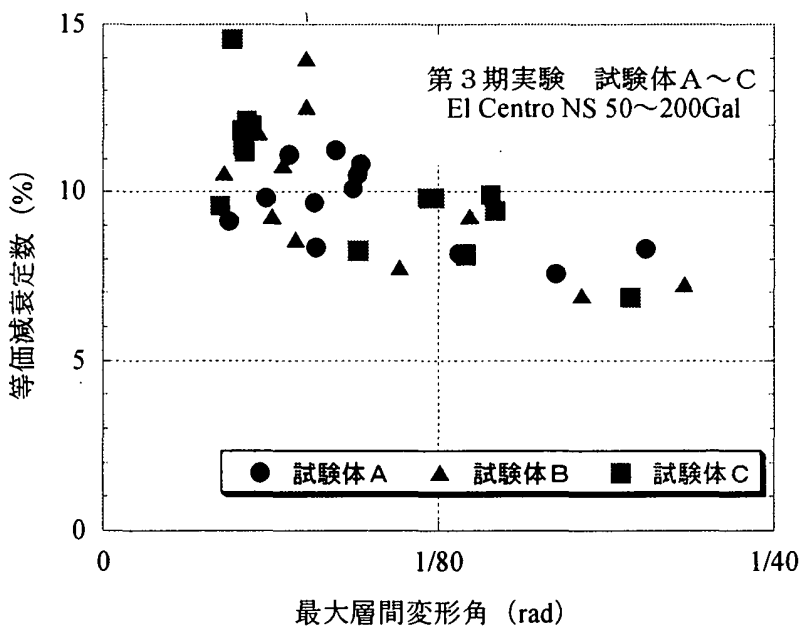

図 18 試験体の等価減衰定数の変化 （第 3 期試験体 A 〜 C E1 Centro NS : 長手方向）

\section{4. まとめ}

本研究では、伝統的木造建築物が有する構造的特徵を盛り込んだ 実大軸組試験体を製作し、振動台実験及び静的水平力載荷実験を 行って、伝統木造軸組の振動特性、復元力特性とともに破壊性状に ついて調べ、得られた実験結果とその考察から以下のようにまとめ られる。

1) 試験体の固有振動数について、常時微動計測の結果からは火打や 貫を堿じた影響はほとんど見られなかったが、スイープ波及び実地 震動波加振実験からは火打や貫を減じた影響が見られた。また、試 験体の減衰定数については、自由振動実験による対数減衰率は約7 〜 $12 \%$ であり、実地震動入力による等価减衰定数 $\mathrm{h}_{\mathrm{eq}}$ は約 5 ～15\% であり、比較的高い减衰性能を示している。柱一貫接合部のモーメ ント抵抗などは、スリップ特性が見られることから伝統的木造軸組 構法建物の減衰性能については、今後、検討を要する。

2) 柱一貫接合部に生じるひび割れは1/40radを超える変形レベルで 多数発生することが、目視観察で確認された。また、仕口形状が単 純通しほぞであった大引仕口の折損が、試験体解体時に確認され た。しかし、試験体の耐力は、試験体各部のひび割れが伸張し、1/ 15radを超える変形レベルにおいても急激に低下寸る傾向はなく、 大引仕口の折損の影響も見られないことから、伝統木造軸組の高い

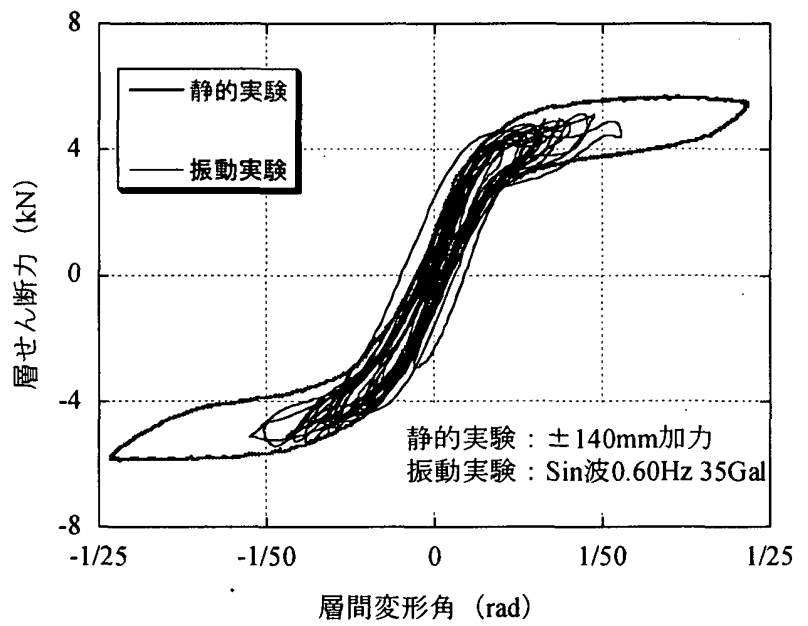

図19 試験体の復元力特性の比較

（第 3 期実験 試験体D：長手方向）

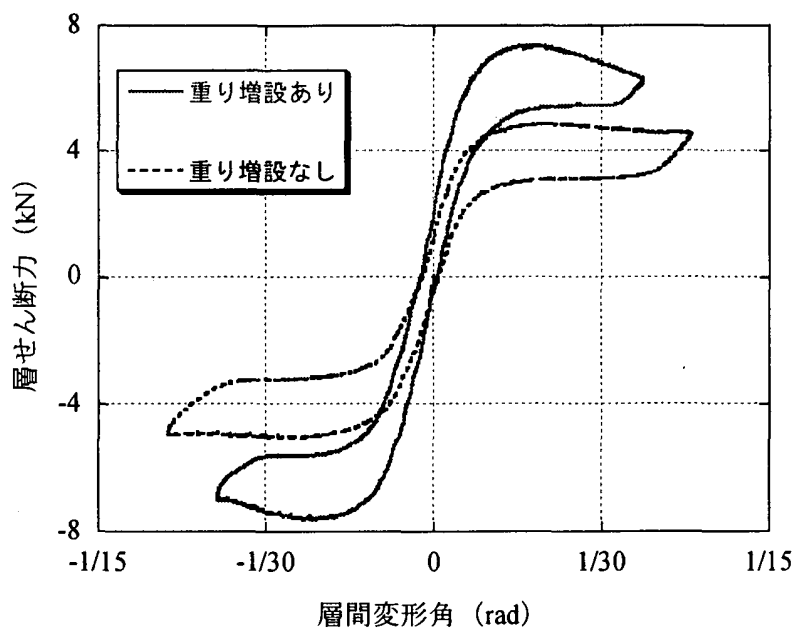

図20 鉛直荷重の増加による試験体の復元力特性の変化 （第 3 期実験 試験体D：長手方向） 
変形性能が明らかとなった。

3）架構全体の復元力は、柱傾斜復元力と横架材によるモーメント抵 抗などから構成されると考えられ、横架材の数が少なくなるに従 い、架構全体の剛性や耐力が低下しており、柱一貫接合部のモーメ ント抵抗は重要な抵抗要素であることが明らかとなった。また、横 架材の数が少ない架構においては、柱傾斜復元力特性がより顕著に 見られ、柱傾斜復元力の鈆直荷重の増加による影響が大きく、架構 全体の復元力に大きく寄与していることが分かった。

今後、伝統木造軸組の復元力特性に大きな影響を与える柱傾斜復 元力特性、さらに組物や柱脚部の挙動、柱一貫接合部のモーメント 抵抗など各部構造要素の詳細な分析等について報告する。

\section{锹辞}

本研究の一部は、科学研究费補助金（基盤研究 $(A)(1)$ 、課題番号: 13305036、研究代表者 : 鈴木样之) 及び平成 11 年度京都市防災対策調査研 究助成金のもとに実施した。また日本建築学会「木椦造と木造文化の再櫣 案」特別研究委員会の研究活動の一理として行った。実験に際して、京都大 学上谷去二教授から贵重なご意見を頂き、材料実験では京都大学木質科学研 究所小松幸平教授、瀧野真二郎助手、森拓郎助手、京都大学大学院農学研究 科の学生諸君、実験では京都大学防災研究所技官市川信夫氏、京都大学大学 院博士課程清水秀丸氏他、京都工芸䋊維大学、金沢工業大学の学生諸君、ビ テオ撮影では金沢工業大学主任技師木谷幸造氏にご協力頂きました。試験体 製作ではアラキ工務店のご協力を、また (株) 鴻池組、(株) 竹中工務店、(株) 大林組からのご支援を頂きました。ここに記して謝意を表します。

\section{参考文献}

1）坂静雄: 社寺骨組の力学的研究 (第 1 部 柱の安定復元力), 日本建築学 会論文集第 21 号, pp252-258, 1941.4
2) Naohito Kawai : Column Rocking Resistance in Japanese Traditi-onal Buildings, Proceeding of the International Wood Engineering Conference Volumn1, pp183-190, 1996.10

3）坂静雄: 社寺骨組の力学的研究（第 2 部 貫の耐力）, 日本建築学会論文集 第 21 号, pp259-268, 1941.4

4）後藤一雄：貫通仕口による木造ラーメン（大黒柱）構造の研究, 日本建築学 会構造系論文集, pp119-125, 1986.8

5）坂本功, 藤田香織他: 伝統的木造建築の組物の振動台実験, 日本建築学会関 東支部研究報告集 (その1) 〜 (その 2), pp37-40,1997, 日本建築学 会大会学術請演梗概集，vol.C - ，（その3）～(その 4), pp263-266, 1998.9，(その5), pp159-160, 1999.9，(その6), pp147-148, 2000.9, (その7), pp171-172, 2001.9

6）藤田香織，木村正彦，大橋好光，坂本功：静的水平加力試験に基つくく伝統的 木造建築の組物の履歴モデルと剛性評価，日本建築学会構造系論文集， No. 543, pp121-127, 2001.5

7）鈴木祥之他：伝統木造軸組の実大振動実験, 日本建築学会大会学術講演梗概 集, Vol. C-1, (その1) 〜 (その12), pp103-126, 2000.9, (その13) 〜 (そ の 19), pp177-190, 2001.9, (その20) 〜 (その23), pp239-246, 2002.8

8）鈴木祥之, 北原昭男, 須田達, 前野将䣣, 西塔純人：伝統木造軸組の実大振 動実釦による動特性、第 11 回日本地震工学シンポジウム, pp. 1349-1354, 2002. 11

9）鈴木祥之, 後藤正美, 大下達哉, 前野将輝：伝統木造軸組の柱傾斜復元力特 性に関する実大静的・動的実験，第11回日本地震工学シンポジウム, pp. 13611366, 2002. 11

10)岩佐裕一，埾原健一，鉿木祥之：仕ロダンパーを用いた伝統木造軸組の耐层 補強一実大振動実験と応答解析一, 第 11 回日本地震工学シンポジウム, pp. $1815-1820,2002.11$

11) 山本雅史, 東野雅彦, 木林長仁, 長瀬正, 佐分利和宏, 鈴木祥之: 粘性体制 霞壁を用いた伝統木造軸組の制震に関する振動台実験, 第11回日本地震工学 シンポジウム, pp. 1809-1814, 2002.11

（2003年 3 月 10 日原稿受理，2003年 9 月 2 日採用決定） 